\title{
Barriers to College and Health Care Careers Among US Students From a Rural Community
}

\author{
Hope H. Bauer, BS | Carter B. Anderson, BS | Kelly Hirko, PhD, MPH | Andrea Wendling, MD
}

PRIMER. 2019;3:10.

Published: 3/25/2019 | DOI: 10.22454/PRiMER.2019.828405

\section{Abstract}

Introduction: Despite rural origin being a strong predictor of rural practice for health care professionals, rural students face educational barriers and are underrepresented in medical schools. The aim of this study was to identify rural high school students' perceived barriers to college and health-related careers and compare whether perceptions were similar based on gender, socioeconomic status (SES), and parental education.

Methods: We performed a cross-sectional survey of all high school students from one rural Michigan community. The survey included 13 multiple-choice and 5 short-answer questions. We compared results using $\chi^{2}$ analysis and logistic regression. Free-text answers were grouped thematically and analyzed for patterns.

Results: Survey response rate was $97.1 \%$ (506/521); $45.3 \%$ (229/506) of students were contemplating health care careers. Rural females were more likely to plan on college (females $83.9 \%$, males $75.6 \%, P=0.03$ ) and to contemplate a health care career (females $64.1 \%$, males $25.2 \%, P<0.01$ ). Students of lower SES and those who would be first-generation college students were less likely to plan on college (SES: low $76.8 \%$, high $84.7 \%$, $P=.04$; parental college: yes $84.4 \%$, no $72.0 \%, P<0.01$ ), although they were equally likely as other students to consider a health care career. Gender and parental education were significant independent predictors of plans for college; female gender was the only significant predictor for health care interest. The most frequently reported barrier to post-high school education was financial, and for health care training, it was academic success.

Conclusions: Rural students are interested in health-related careers. Addressing perceived academic and financial barriers for students from high-need rural communities may inform targeted interventions to increase the rural health care workforce.

\section{Introduction}

Many rural communities face a shortage of health care workers. ${ }^{1}$ Studies have consistently supported two health care educational interventions: selective admission of rural students, and rural clinical training opportunities, with longer exposure more strongly associated with rural practice. ${ }^{2-7}$ Despite this evidence, rural students remain underepresented in health professional programs. ${ }^{8-10}$ This is often due to educational and socioeconomic challenges for these rural students, rather than admission bias. ${ }^{11-14}$ Rural students are less likely to graduate from high school, less likely to attend college, and much less likely to graduate from college than their peers from urban schools. ${ }^{13,14}$ This results in a lower proportion of rural students applying to health professional programs, and consequently fewer rural health care workers than would be expected by population demographics. ${ }^{8,9,15}$

Understanding the barriers rural high school students face may inform pipeline programs and help target interventions to bolster the rural health care workforce. A Canadian study showed that rural students are less likely 
than urban students to contemplate health care careers, ${ }^{16}$ with barriers postulated including distance to education, finances, and lack of role models. ${ }^{17,18}$ An Australian qualitative study supported distance, cost, and insufficient information as barriers. ${ }^{19}$ However, no studies have explored this issue from the perspective of rural US high school students. The aim of this pilot study was to identify interest in and perceived barriers to higher education and healthrelated careers, as reported by high school students from an isolated rural community in Michigan.

\section{Methods}

This cross-sectional study explored rural students' educational and career goals and perceived educational barriers. The survey included five demographic questions, seven questions about educational and career plans, and one question exploring students' perceptions of the impact of rural upbringing. Students also listed educational barriers using free text.

Alpena, Michigan (population 10,122$)^{20}$ is the largest population center of Alpena County, a rural county in Northern Michigan. ${ }^{21}$ Alpena is assigned a Rural Urban Continuum Code of 7 (Nonmetro-Urban population of 2,500 to 19,999, not adjacent to a metro area), ${ }^{22}$ a Frontier and Remote Area Level 2 (areas where the majority of the population lives 60 minutes or more from urbanized areas, ${ }^{23}$ and is a medically underserved population. ${ }^{24} \mathrm{~A}$ survey was administered anonymously via Google Forms to all students attending Alpena High School from February 3-12, 2017, who did not opt out of participation via a parental consent form. Students had an additional opt-out option on the survey itself.

Data was analyzed using IBM SPSS Statistics, version 24. Responses were compared using $\chi^{2}$ and logistic regression, with significance set at $P<0.05$. Two researchers separately coded free-text quotes and grouped them into themes using immersion and crystallization. Codes and themes were cross checked, and any discrepancies were discussed until consensus was reached. Frequency of quotes was compared within each theme through counts of individuals.

The Munson Medical Center Institutional Review Board determined the project was exempt.

\section{Results}

Survey response rate was $97.1 \%$ (506/521); 274 respondents (54.2\%) identified as female, 209 (41.3\%) male, and the remaining 23 (4.5\%) did not identify as either gender; 459 (90.7\%) were Caucasian. The majority planned on attending college (80.2\%). See Table 1 for student demographic information and educational/career plans.

Table 2 delineates student interest in a health care career as related to gender, socioeconomic status (as measured by eligibility for free or reduced lunch), and parental education. High school females in our study pool were more likely to plan on attending college and to contemplate a health care career. Students of lower SES and those who would be first-generation college students were less likely to plan on college, although they were equally likely as other students to be considering a health care career. Multivariate logistic regression models were constructed for college plans and health care interest using gender, SES, and parental education as independent variables. Gender and parental education were significant independent predictors of plans for college (female gender odds ratio [OR] 2.0, $P<0.01$; parental college OR 2.6, $P<0.01$; full model $\chi^{2}[3, N=444]=20.9, P<0.01$ ). With regression modeling of the impact of these three variables on health care interest, gender was the only significant independent predictor (female OR 4.9, $P<0.01$; full model $\chi^{2}[3, \mathrm{~N}=434]=65.1, P<0.01$ ).

Education/work plans and perception of rural impact were also compared by student class level. There were no significant differences by class level in any education or work plans or in the perception of rural impact, with one exception. Of the four classes, freshman were most likely to respond "yes" or "maybe" to plans for a master's or doctorate degree $(130 / 145,89.6 \%)$ and seniors were the least likely $(64 / 72,71.9 \% ; P=0.01)$.

Short-answer responses describing barriers were grouped thematically (Table 3 ). The most frequently reported perceived barriers to college were financial (Figure 1), while the most frequently reported barriers to pursuing health care careers were academic concerns (Figure 2). 


\section{Conclusions}

This study of educational goals, health care-related career plans, and barriers as perceived by high school students from a rural county in Michigan shows that although many rural students contemplate college and health care careers, these students anticipate significant barriers including financial, academic, and social concerns. Understanding and addressing these perceived barriers early in rural students' education may help to alleviate concerns ${ }^{25}$ and increase the likelihood of college attendance and success.

This study supports previous work demonstrating a relationship between parental education and likelihood of considering college, although SES did not remain a significant predictor-a difference from previous work. ${ }^{14,26}$ Providing rural high schoolers with mentorship and encouragement-especially for those without family experience with higher education-may be an effective community-based educational strategy to address this initial barrier.

Many rural students' concerns about college success and health care career training were centered around financial issues, with some eliminating options early because financial concerns were so high. Counseling rural students early in their high school years about need-based educational scholarships and grants, loan repayment opportunities for rural health professionals, and programs such as the National Health Service Corps could potentially address financial concerns.

Students were concerned about their readiness for college studies. Academic concerns could be addressed through guidance counselors and career mentors, who could provide information about academic requirements for various programs. Rural high schools could invite alumni who are successfully attending college, recent college graduates, and those enrolled in health professional programs to speak about their experience to current high school students. Seeing graduates from their own high schools successfully navigating these educational paths may help rural students better visualize their own success.

This study had several limitations, the most important being that only one rural Michigan county was surveyed, limiting generalizability. The survey combined health-related careers when inquiring about interest, limiting information about specific health care paths. The survey also did not provide a definition of "health care career," which may have affected responses.

Understanding the financial and academic concerns of high school students from high-need rural communities may help inform targeted strategies to address these concerns, and potentially increase medical practitioners in rural communities in the future.

\section{Tables and Figures}


Table 1: Participant Demographics, Educational and Career plans, and Perceived Rural Impact

\begin{tabular}{|c|c|c|c|}
\hline \multirow{13}{*}{ Demographics } & \multirow{3}{*}{ Gender } & Female & $274(54.2 \%)$ \\
\hline & & Male & 209 (41.3\%) \\
\hline & & Other/prefer not to say & $23(4.5 \%)$ \\
\hline & \multirow{4}{*}{ Grade } & Freshman & $149(29.4 \%)$ \\
\hline & & Sophomore & $134(26.5 \%)$ \\
\hline & & Junior & $132(26.1 \%)$ \\
\hline & & Senior & $91(18.0 \%)$ \\
\hline & \multirow{6}{*}{ Race } & Asian/Pacific Islander & $7(1.4 \%)$ \\
\hline & & Black/African American & $10(2.0 \%)$ \\
\hline & & Hispanic & $6(1.2 \%)$ \\
\hline & & Native American & $6(1.2 \%)$ \\
\hline & & White/Caucasian & $459(90.7 \%)$ \\
\hline & & Other/prefer not to say & $18(3.6 \%)$ \\
\hline \multirow{6}{*}{$\begin{array}{l}\text { Socioeconomic } \\
\text { status }\end{array}$} & \multirow{3}{*}{$\begin{array}{l}\text { Did either of your parents complete a } \\
\text { college degree? }\end{array}$} & Parent with college degree & $340(67.2 \%)$ \\
\hline & & No college degree & $164(32.4 \%)$ \\
\hline & & Did not answer & $2(0.4 \%)$ \\
\hline & \multirow{3}{*}{$\begin{array}{l}\text { Are you eligible to receive free or } \\
\text { reduced lunch? }\end{array}$} & Yes & $185(36.6 \%)$ \\
\hline & & No & $281(55.5 \%)$ \\
\hline & & Did not answer & $40(7.9 \%)$ \\
\hline \multirow{18}{*}{$\begin{array}{l}\text { Education and } \\
\text { work plans: }\end{array}$} & \multirow{2}{*}{...complete high school? } & Yes & $499(99.6 \%)$ \\
\hline & & No & $7(1.4 \%)$ \\
\hline & \multirow{2}{*}{$\begin{array}{l}\text {...enter the workforce directly after high } \\
\text { school? }\end{array}$} & Yes & $192(37.9 \%)$ \\
\hline & & No & $314(62.1 \%)$ \\
\hline & \multirow{2}{*}{...attend a trade school? } & Yes & $65(12.8 \%)$ \\
\hline & & No & $441(87.2 \%)$ \\
\hline & \multirow{2}{*}{$\begin{array}{c}\text {...attend a 2-year college, such as a } \\
\text { community college? }\end{array}$} & Yes & $306(60.5 \%)$ \\
\hline & & No & $200(39.5 \%)$ \\
\hline & \multirow{2}{*}{$\begin{array}{c}\text {... attend a four-year college or } \\
\text { university? }\end{array}$} & Yes & $406(80.2 \%)$ \\
\hline & & No & $100(19.8 \%)$ \\
\hline & \multirow{4}{*}{$\begin{array}{c}\text {...pursue a master's degree or } \\
\text { doctorate? }\end{array}$} & Yes & $209(41.3 \%)$ \\
\hline & & No & $85(16.8 \%)$ \\
\hline & & Maybe & $198(39.1 \%)$ \\
\hline & & Did not answer & $14(2.8 \%)$ \\
\hline & \multirow{4}{*}{$\begin{array}{l}\text { Are you interested in a health care } \\
\text { career? }\end{array}$} & Yes & $144(28.5 \%)$ \\
\hline & & No & $266(52.6 \%)$ \\
\hline & & Maybe & $85(16.8 \%)$ \\
\hline & & Did not answer & $11(2.2 \%)$ \\
\hline \multirow{3}{*}{ Rural impact } & \multirow{3}{*}{$\begin{array}{c}\text { Do you believe being from a rural area } \\
\text { will affect your ability to pursue your } \\
\text { goals? }\end{array}$} & $\begin{array}{l}\text { Yes-it will make it harder for me to achieve } \\
\text { my goals. }\end{array}$ & $159(31.4 \%)$ \\
\hline & & Yes-it will make it easier to achieve my goals. & $61(12.1 \%)$ \\
\hline & & $\begin{array}{c}\text { No-it will not make it easier or harder to } \\
\text { achieve my goals. }\end{array}$ & $286(56.5 \%)$ \\
\hline
\end{tabular}


Table 2: Interest in College and Health Care Careers Based on Students' Gender, SES, and Parental Education

\begin{tabular}{|c|c|c|c|c|c|c|c|}
\hline & & \multicolumn{3}{|c|}{ Planning College } & \multicolumn{3}{|c|}{ Contemplating Health Care ${ }^{\dagger}$} \\
\hline & & Yes & No & $P$ Value & Yes & No & $P$ Value \\
\hline \multirow{2}{*}{ Gender } & Female & $\begin{array}{c}230 \\
(83.9 \%)\end{array}$ & $\begin{array}{c}44 \\
(16.1 \%)\end{array}$ & \multirow{2}{*}{$\begin{array}{c}4.7 \\
P=0.03^{*}\end{array}$} & $173(64.1 \%)$ & $97(35.9 \%)$ & \multirow{2}{*}{$\begin{array}{c}68.3 \\
P<0.01^{*}\end{array}$} \\
\hline & Male & $\begin{array}{c}158 \\
(75.6 \%)\end{array}$ & $\begin{array}{c}51 \\
(24.4 \%)\end{array}$ & & $51(25.2 \%)$ & $\begin{array}{c}151 \\
(74.8 \%)\end{array}$ & \\
\hline \multirow{2}{*}{ SES } & Low & $\begin{array}{c}142 \\
(76.8 \%) \\
\end{array}$ & $\begin{array}{c}43 \\
(23.2 \%) \\
\end{array}$ & \multirow{2}{*}{$\begin{array}{c}4.12 \\
P=0.04\end{array}$ * } & $81(45.0 \%)$ & $99(55.0 \%)$ & \multirow{2}{*}{$\begin{array}{c}.326 \\
P=0.57\end{array}$} \\
\hline & High & $\begin{array}{c}238 \\
(84.7 \%)\end{array}$ & $\begin{array}{c}43 \\
(15.3 \%)\end{array}$ & & $133(48.2 \%)$ & $\begin{array}{c}143 \\
(51.2 \%)\end{array}$ & \\
\hline \multirow{2}{*}{$\begin{array}{l}\text { Parental } \\
\text { education }\end{array}$} & College degree & $\begin{array}{c}287 \\
(84.4 \%)\end{array}$ & $\begin{array}{c}53 \\
(15.6 \%)\end{array}$ & \multirow{2}{*}{$\begin{array}{c}10.1 \\
P<0.01^{*}\end{array}$} & $147(44.0 \%)$ & $\begin{array}{c}187 \\
(56.0 \%)\end{array}$ & \multirow{2}{*}{$\begin{array}{c}1.81 \\
P=0.15\end{array}$} \\
\hline & $\begin{array}{l}\text { No college } \\
\text { degree }\end{array}$ & $\begin{array}{c}118 \\
(72.0 \%)\end{array}$ & $\begin{array}{c}46 \\
(28.0 \%)\end{array}$ & & $81(50.9 \%)$ & $78(49.1 \%)$ & \\
\hline
\end{tabular}

Total values do not consistently equal 506 because responses of "other" or "prefer not to say" were excluded from analysis.

† Students who chose "yes" or "maybe" in response to the question "Are you interested in a healthc are career?" were designated as contemplating health care. Abbreviation: SES, socioeconomic status, as based on participant reporting of eligibility for free or reduced lunch (low) or denying eligibility (high).

* Statistically significant differences; $P<0.05$. 


\section{Table 3: Barriers to College and Health Care Careers: Themes and Example Quotations From Rural High School Students}

\section{Barriers to College Education: Themes and Example Quotations From Rural High School Students}

\begin{tabular}{|c|c|}
\hline $\begin{array}{l}\text { Academic } \\
\text { concerns }\end{array}$ & $\begin{array}{l}\text { - The schooling will be very difficult and it will be hard to keep up. } \\
\text { - I struggle in certain subjects and l'm worried I won't do well in my classes. } \\
\text { - The disadvantage of having gone to a small school without large AP or Honors programs. }\end{array}$ \\
\hline Distance concerns & $\begin{array}{l}\text { - Missing home } \\
\text { - Distance, I don't want to be too far from home. } \\
\text { - Having to travel long distances to a university; making it hard to visit home }\end{array}$ \\
\hline Financial concerns & $\begin{array}{l}\text { - The only barrier I expect to face is the debt I will owe on my education. College will be extremely expensive } \\
\text { and it's scary to consider how much it will cost. } \\
\text { - Money is tight. } \\
\text { - Getting scholarships is a major concern of mine as my parents can't pay for my education. }\end{array}$ \\
\hline Social concerns & $\begin{array}{l}\text { - Friends, unfamiliar ground, and stress } \\
\text { - I'm used to living in a small town and moving will be a change }\end{array}$ \\
\hline $\begin{array}{l}\text { Concerns related } \\
\text { to college }\end{array}$ & $\begin{array}{l}\text { - It will be difficult to find the right college. } \\
\text { - The college application or signing up for classes }\end{array}$ \\
\hline $\begin{array}{l}\text { Specific personal } \\
\text { concerns }\end{array}$ & $\begin{array}{l}\text { Medical disorders that slow down my work will be a barrier for me. } \\
\text { My family has no enthusiasm for my success, so I wouldn't get the support I need. }\end{array}$ \\
\hline \multicolumn{2}{|c|}{ Barriers to Health Care Careers: Themes and Example Quotations From Rural High School Students } \\
\hline $\begin{array}{l}\text { Academic } \\
\text { concerns during } \\
\text { training }\end{array}$ & $\begin{array}{l}\text { - I may have trouble disciplining myself to study and put time into my work in college since I find school } \\
\text { currently to be very easy. } \\
\text { - I am going to have to get a job, so studying and focusing solely on my education will be impossible. }\end{array}$ \\
\hline Financial concerns & $\begin{array}{l}\text { - Money; the cost of schooling for health care careers is higher than most other careers because you usually } \\
\text { go to school longer depending on what exactly you want to go into. }\end{array}$ \\
\hline $\begin{array}{l}\text { Concerns about } \\
\text { the career }\end{array}$ & $\begin{array}{l}\text { - Dealing with gross things you don't want to deal with, but is part of your job } \\
\text { - Deaths of patients, sad stories, and long work hours } \\
\text { - Seeing things that will scar or hurt you }\end{array}$ \\
\hline Time concerns & - The many years of schooling involved \\
\hline $\begin{array}{l}\text { Specific personal } \\
\text { concerns }\end{array}$ & $\begin{array}{l}\text { - Adjusting to the atmosphere; there are going to be a lot more people than I am used to. } \\
\text { - I won't really be able to have a relationship with any of my professors like I have with my high school } \\
\text { teachers and this is going to take some getting used to. } \\
\text { - The risk of failure. }\end{array}$ \\
\hline $\begin{array}{l}\text { Difficult to enter } \\
\text { program }\end{array}$ & $\begin{array}{l}\text { - I think that nurse practitioner schools will be very competitive so l'm expecting to face some obstacles in } \\
\text { entering further schooling. }\end{array}$ \\
\hline Lack of job security & $\begin{array}{l}\text { - Location, there are no labs near here so it will be hard to find a job, even if I have to move. } \\
\text { - The availability of a job }\end{array}$ \\
\hline Rural area & $\begin{array}{l}\text { - The distance to school } \\
\text { - Being from a small town [is a barrier]. }\end{array}$ \\
\hline
\end{tabular}


Figure 1: Categories of Barriers to Postsecondary Education and Frequency of Comments per Category, as Described by Rural High School Students

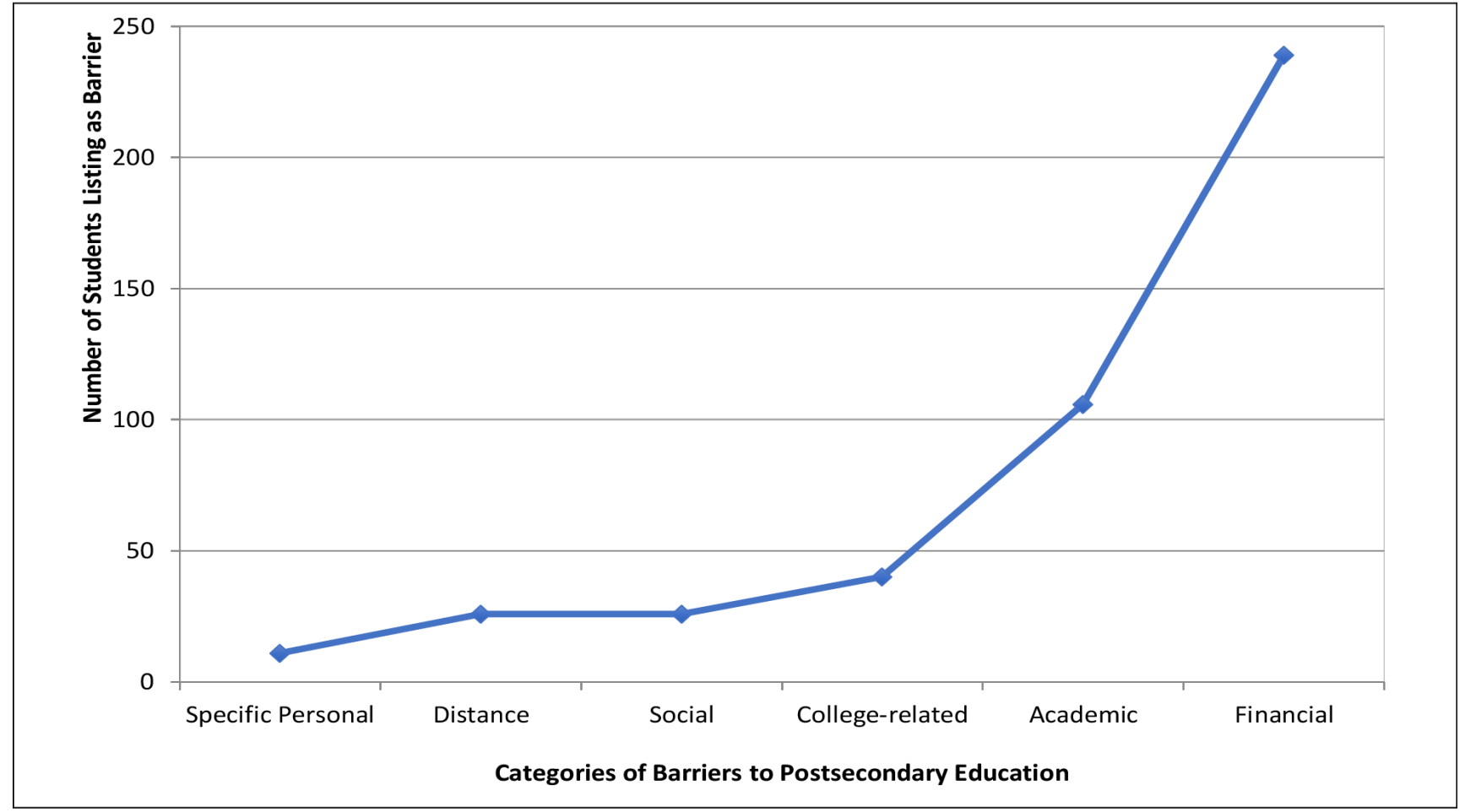

Figure 2: Categories of Barriers to Health Care Careers and Frequency of Comments per Category, as Described by Rural High School Students

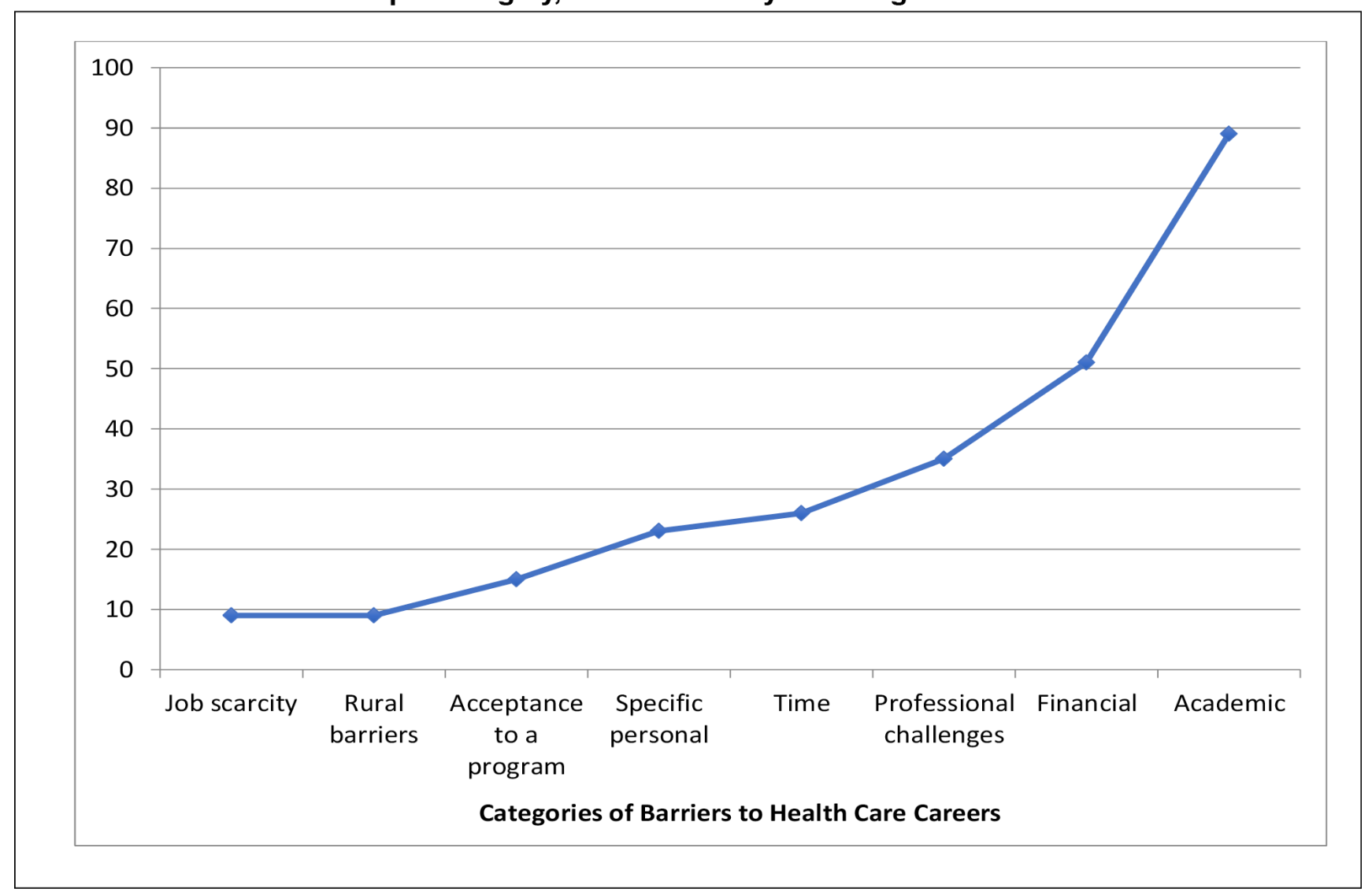

\section{Acknowledgments}




\section{Presentations:}

1. Family Medicine Midwest Conference, October 8, 2017, Rosemont, IL. (Poster Presentation)

2. National Rural Health Association Annual Rural Health Conference, May 10, 2017, San Diego, CA. (Poster Presentation)

3. Society of Teachers in Family Medicine Annual Spring Conference, May 7, 2017, San Diego, CA. (Poster Presentation)

\section{Corresponding Author}

Andrea Wendling, MD

East Fee Hall, 965 Fee Rd, Room A118, East Lansing, Ml 48824.

wendli14@msu.edu

\section{Author Affiliations}

Hope H. Bauer, BS - Michigan State University College of Human Medicine

Carter B. Anderson, BS - Michigan State University College of Human Medicine

Kelly Hirko, PhD, MPH - Department of Epidemiology and Biostatistics, Michigan State University College of Human Medicine, Traverse City, MI

Andrea Wendling, MD - Michigan State University College of Human Medicine, East Lansing, MI

\section{References}

1. Doescher MP, Fordyce SM, Skillman SM, Jackson E, Rosenblatt R. Persistent Primary Care Health Professional Shortage Areas (HPSAs) and Health Care Access in Rural America. WWAMI Rural Health Research Center, September 2009. http://depts.washington.edu/uwrhrc/uploads/Persistent_HPSAs_PB.pdf. Accessed March 7, 2018.

2. Phillips RL, Petterson S, Xierali I, Bazemore A, Teevan B, Bennett K, et al. Specialty and Geographic Distribution of the Phyisician Workforce: What Influences Medical Student and Resident Choices? Washington, DC: Robert Graham Center. http://www.graham-center.org/dam/rgc/documents/publications-reports/monographsbooks/Specialty-geography-compressed.pdf. Accessed March 7, 2018.

3. Wilson NW, Couper ID, De Vries E, Reid S, Fish T, Marais BJ. A critical review of interventions to redress the inequitable distribution of healthcare professionals to rural and remote areas. Rural Remote Health. 2009;9(2):1060.

4. Playford DE, Nicholson A, Riley GJ, Puddey IB. Longitudinal rural clerkships: increased likelihood of more remote rural medical practice following graduation. BMC Med Educ. 2015;15(1):55. https://doi.org/10.1186 /s12909-015-0332-3

5. Brooks RG, Walsh M, Mardon RE, Lewis M, Clawson A. The roles of nature and nurture in the recruitment and retention of primary care physicians in rural areas: a review of the literature. Acad Med. 2002;77(8):790-798. https://doi.org/10.1097/00001888-200208000-00008

6. Ballance D, Kornegay D, Evans P. Factors that influence physicians to practice in rural locations: a review and commentary. J Rural Health. 2009;25(3):276-281. https://doi.org/10.1111/j.1748-0361.2009.00230.x

7. Rabinowitz HK, Diamond JJ, Markham FW, Wortman JR. Medical school programs to increase the rural physician supply: a systematic review and projected impact of widespread replication. Acad Med. 2008;83(3):235-243. https://doi.org/10.1097/ACM.0b013e318163789b

8. American Academy of Physician Assistants. 2013Academy of Physicians Assistants Annual Survey Report. http://kc.edu/wp-content/uploads/2015/11/2013-AAPA-annual-report.pdf. Accessed September 12, 2017.

9. US Department of Health and Human Services. The US Nursing Workforce: Trends in Supply and Education. Health Resource and Services Administration. https://www.ruralhealthinfo.org/pdf/nursing-workforce-nchwareport-april-2013.pdf. Accessed September 12, 2017.

10. Hutten-Czapski P, Pitblado R, Rourke J. Who gets into medical school? Comparison of students from rural and 
urban backgrounds. Can Fam Physician. 2005;51:1240-1241.

11. Basco WT Jr, Gilbert GE, Blue AV. Determining the consequences for rural applicants when additional consideration is discontinued in a medical school admission process. Acad Med. 2002;77(10)(suppl):S20S22. https://doi.org/10.1097/00001888-200210001-00007

12. Hensel JM, Shandling M, Redelmeier DA. Rural medical students at urban medical schools: too few and far between? Open Med. 2007;1(1):e13-e17.

13. Byun SY, Meece JL, Irvin MJ. Rural-Nonrural Disparities in Postsecondary Educational Attainment Revisited. Am Educ Res J. 2012;49(3):412-437. https://doi.org/10.3102/0002831211416344

14. Walpole M. Socioeconomic Status and College: How SES affects college experiences and outcomes Rev Higher Educ.2003;27(1):45-73. https://doi.org/10.1353/rhe.2003.0044

15. Doescher MP, Skillman SM, Rosenblatt RA. The Crisis in Rural Primary Care. WWAMI Rural Health Research Center Policy Brief. April 2009. https://depts.washington.edu/uwrhrc/uploads /Rural_Primary_Care_PB_2009.pdf. Accessed September 18, 2017.

16. Whalen D, Harris C, Harty C, et al. Should I apply to medical school? High school students and barriers to application. Can J Rural Med. 2016;21(2):46-50.

17. Rourke J, Dewar D, Harris K, et al; Task Force of the Society of Rural Physicians of Canada. Strategies to increase the enrollment of students of rural origin in medical school: recommendations from the Society of Rural Physicians of Canada. CMAJ. 2005;172(1):62-65. https://doi.org/10.1503/cmaj.1040879

18. Cassidy K, Foster T, Moody E, Turner J, Tejpar S. Perceptions of medical school among high school students in southwestern Ontario. Can J Rural Med. 2013;18(1):7-12.

19. Durey A, McNamara B, Larson A. Towards a health career for rural and remote students: cultural and structural barriers influencing choices. Aust J Rural Health. 2003;11(3):145-150. https://doi.org/10.1046 /j.1440-1584.2003.00481.x

20. US Census Bureau QuickFacts. Population Estimates, July 1, 2016. https://www.census.gov/quickfacts /fact/table/alpenacitymichigan,alpenacountymichigan. Accessed November 29, 2017.

21. Rural Health Information Hub. Am I Rural? - Report. Alpena, Michigan [search query]. https://www.ruralhealthinfo.org/am-i-rural. Accessed March 31, 2018.

22. United States Department of Agriculture, Economic Research Service. Rural-Urban Continuum Codes. https://www.ers.usda.gov/data-products/rural-urban-continuum-codes/. Accessed March 7, 2018.

23. US Department of Agriculture, Economic Research Service. Frontier and Remote Area Codes. https://www.ers.usda.gov/data-products/frontier-and-remote-area-codes/documentation/. Accessed March 31, 2018.

24. Health Resources and Services Administration Data Warehouse. Shortage Areas. https://datawarehouse.hrsa.gov/topics/shortageAreas.aspx. Accessed March 31, 2018.

25. Robinson MA, Douglas-Vail MB, Bryce JN, van Zyl TJ. Medical school outreach and mentorship for rural secondary school students: a pilot of the Southwestern Ontario Medical Mentorship Program. Can J Rural Med. 2017;22(2):62-67.

26. Astin A, Oseguera L. The declining 'equity' of American higher education. The Rev Higher Educ.2004;27(3):321-341. https://doi.org/10.1353/rhe.2004.0001

Copyright $@ 2019$ by the Society of Teachers of Family Medicine 